\title{
Social capital under conditions of ethnic conflict: how does social capital impact on development in micro settings?
}

\author{
Dhammika Herath * \\ Department of Sociology, Faculty of Arts, University of Peradeniya, Peradeniya, Sri Lanka.
}

\begin{abstract}
This paper examines the causal relationship between social capital and development in micro settings at a time of violent conflict by taking a case study of six villages in the north of Sri Lanka. The rich and vast literature on social capital has documented the causal linkages between social capital and the various social and economic outcomes, which, among others include development, better functioning democracies, ethnic harmony, and so on. This particular paper is focusing on micro settings to seek whether social capital is a significant factor of development in such settings, especially, at a time when these settings have gone through violent conflict, where people have been set apart by cleavages of ethnicity and/or religion. This requires understanding and measuring both social capital and development in a manner sensitive and meaningful for micro settings. Relatively, few studies show how this can be achieved and hence the research gap. This study finds that bonding social capital is a strong factor in development in terms of supporting agriculture even at a time of conflict. Bonding social capital is important in converting natural resources into economic assets which improve the level of development. Bridging social capital has had historical significance not only in agriculture but also in many other aspects. An equally important objective of the paper is to illustrate how a mixed-method approach of using both qualitative and quantitative techniques can be used for social capital research. Most studies on social capital depend either on quantitative or qualitative methods and fail to capture the intricate dynamics between components of social capital and development outcomes. This particular study shows how social capital can be measured using the indicators that local people suggest, so that, the indexes developed actually measure what is important for the people.
\end{abstract}

Keywords: Social capital, development, conflict, post-war, Sri Lanka.

\section{INTRODUCTION}

The research study, reported in this article, became a reality at a particular historical juncture in the long drawn-out violent conflict between the government of Sri Lanka (GoSL) and the Liberation Tigers of Tamil Eelam (LTTE). In 2002, a ceasefire came into effect between these parties and, consequently, there emerged a renewed discussion about the reconstruction of the war-torn northeast through development. In similar conflict-affected environments, there have been studies which have investigated the relevance of social capital for development (Colletta \& Cullen, 2000; Colletta et al., 2001). However, in Sri Lanka, relatively little was known about the dynamics of conflict and social capital for development at the village level. Therefore, it was necessary to know whether social capital would have the power to explain relatively higher development in some villages and lower development in others in conflictaffected areas. Further, given the significance of ethnicity in the conflict, it was important to examine how ethnicity was related to levels of social capital. The development discourse in Sri Lanka is built around state intervention and, to some extent, on the contribution of nongovernmental organisations. However, this particular study draws attention on hitherto relatively unexplored aspect on social factors in development in a situation of violent conflict. Therefore, this study was developed to investigate the potential causal relationships between social capital and development in six selected villages in northern Sri Lanka ${ }^{1}$.

Another equally important goal of this paper is to highlight the significance of a mixed method approach to study social capital and development outcomes. The social capital literature is rich and vast. Many social capital studies have adopted a macro approach in which countries, provinces or districts become subject to academic scrutiny most often through the surveys,

*Corresponding author (dhammikaherath@pdn.ac.lk; (iD https://orcid.org/0000-0002-2707-6596)

This article is published under the Creative Commons CC-BY-ND License (http://creativecommons.org/licenses/

by-nd/4.0/). This license permits use, distribution and reproduction, commercial and non-commercial, provided that the original work is properly cited and is not changed anyway. 
while some studies make use of textual evidence to speak about the history of a particular case. There are also many studies that depend purely on qualitative methods. While both these approaches are important in educating on the impact of social capital, this study attempts to illustrate how context and culture sensitive indicators can be developed through a mix of qualitative and quantitative techniques. Instead of going to the field with pre-coded instruments, this study has attempted to measure social capital through indicators that came up in qualitative interviews. These indicators were then used to develop quantitative measures, which complimented the qualitative interviews in studying the linkage between social capital and development outcomes.

\section{Social capital: concepts and definitions}

Loury, an economist, invoked the term 'social capital' in late 1970s, but the intellectual content of the concept has been in vogue for much of academic history. Writings from thinkers and philosophers, ranging from George Simmel, Max Weber to Emile Durkheim, have contained the roots of social capital (Portes \& Sensenbrenner, 1993; Portes, 1998; Westlund \& Adam, 2010; Woolcock, 1998). Bourdieu (1986) has a discussion of 'capital', which is deep and rich in many respects, notwithstanding that it does not figure prominently among social capital debates. He explains inter-linkages between different forms of 'capital', which appears in three forms, as 'economic capital', 'cultural capital' and 'social capital' (Bourdieu, 1998; 1986: pp. 241-257; 1990: pp.112-121; Brubaker, 1985; Harker, 1990). Coleman (1988; 1993) was one of the first to take social capital into theoretical discussions in sociology. Further, Putnam has figured prominently in the contemporary discussions on social capital. Putnam, through his seminal studies in Italy and United States, tries to show that norms and networks of civic engagement strongly influence the quality of public life and the performance of public institutions (Putnam, 1993; 1995(a); 1995(b); Putnam et al., 1993; Helliwell \& Putnam, 1995). Many researchers have attempted to produce empirical evidence that supports the theoretically expected relationship between horizontal associations of people and economic benefits (Amunugama, 1964; Dissanayake, 1991; Jayamaha, 1990; Narayan, 1999). Fukuyama (1995) states that, the ability of strangers to trust one another and to work together in new and flexible forms of organisation is crucial for economic development. There are also structurally focused definitions examining how people productively work with other people (Malecki, 2012).

The social capital thesis centres on the assumption that when a certain community is endowed with trust, networks and reciprocity, these stocks of social capital make possible the achievement of socio-economic benefits such as higher incomes, higher economic growth, better education, better health, higher agricultural production, soil and water conservation and adoption of new technologies in agriculture, and betterfunctioning democracies, less conflicts, moral behavior etc., that would not be possible in a community lacking social capital (Fox, 1997; Gidwani, 2000; Hulme \& Shepherd, 2003; Husen et al., 2017; King \& Furrow, 2004; Knack \& Keefer, 1997; Knack, 2002; Narayan, 1999; Narayan \& Pritchett, 1997; 2000; Paxton, 2002; Portes \& Sensenbrenner, 1993; Putnam, 1995a; D' Silva \& Pai, 2003; Uphoff et al., 1998; Uphoff, 2000; Uslaner \& Conley, 2003; Widmalm, 2005; Woolcock, 2002). Studies have suggested that social capital helps women's enterprises by giving them better access to other forms of capital, business advice, information regarding business opportunities and better access to financing (Kelley et al., 2010; Mozumdar et al., 2017). Recent research also demonstrates the relevance of social capital for wellbeing under development induced displacement (QuetulioNavarra et al., 2017).

The dominant trend in social capital literature is to associate favourable development outcomes with bridging social capital, while some studies consider strong bonding social capital as a hindrance to development (Colletta \& Cullen, 2000; Colletta et al., 2001; Eklinder-Frick et al., 2012; Fox, 1997; Narayan, 1999; Putnam, 1995b; Paxton, 2002; Uslaner \& Conley, 2003) although a few studies have argued that bonding social capital has a favourable impact on these outcomes (D' Silva \& Pai, 2003; Gidwani, 2000; McShane et al., 2016; Michelini et al., 2013; Portes \& Sensenbrenner, 1993; Widmalm, 2005). A third category of social capital known as 'lining' social capital, involving relationships between people of different levels of power and authority also affects development (Grootaert et al., 2004; Taruvinga et al., 2017; Woolcock, 1998). While many of these studies highlight the significance of social capital as a causal factor, there are other studies which asserts that community driven projects contribute to increasing social capital stocks among the rural communities (Nejadi et al., 2017).

However, some studies highlight the potentially negative effects of social capital as well. There are criticisms about the usability of the concept of social capital in the analysis of development outcomes. Some reject the relevance of social capital and argue that social capital studies have failed to grasp vital political aspects that influence the said favourable outcomes (Fine \& Green, 2000; Fine, 1999; 2003; Harris, 2001; Harris \& De Renzio, 1997; Lin, 1999; Portes, 1998; 2000; Sobel, 2002). Undoubtedly these critics present valid arguments, which need serious attention. Definitional circularity has to be overcome through careful distinction 
between the sources, dimensions and outcomes of social capital. It is necessary that researchers maintain clarity about the conceptual and operational definition of social capital. There is certainly a need to closely analyse political processes and power relations before one can draw conclusions about development. In any case, the beneficial outcomes through stocks of social capital may not be arising from social capital alone.

\section{METHODOLOGY}

This research study was carried out with a blend of qualitative and quantitative data gathering methods. The study was initiated with initial observations in the northeast of Sri Lanka and then, after choosing the district of Vavuniya for the study, a research methodology for this study was developed. Data for the study were collected through close observations, collection of official records, interviews with key state officials and nonstate $^{2}$ representatives, 41 in-depth interviews and case studies with key informants and ordinary villagers. All the interviewees for qualitative data were chosen through purposive and snowball sampling. Further, a survey of 416 households in the six villages was conducted. Existing contacts in the district were helpful in locating knowledgeable informants initially. In order to test whether social capital correlate with rural development in conflict-affected micro settings, this study developed a specific research model of six villages. Given the significance of ethnicity in the conflict, it was necessary to include villages of three ethnic groups: Sinhalese, Tamil and Muslim. Then, in order to compare the levels of development, the study included one poor and one non-poor village from each ethnic group ${ }^{3}$. The study used a combination of sources to chose the six study villages including the official classification of villages into poor and non-poor villages, authors' own observations and interviews with civil society leaders in Vavuniya. Each of the six villages was ethnically homogenous and the number of households varied roughly between 60 and 90 .

Critical pragmatic factors influenced the choice of Vanuniya as against other possible localities in the Northeast. This study was carried out at a time when the intrastate conflict between GoSL and LTTE prevented access to many other areas of the Northeast. Further, tsunami of December 2004 had devastated many of the localities in the Northeast, thus, effectively making it practically difficult to carry out a research study in many areas. Vavuniya became an obvious choice because this area was relatively less violent and unaffected by tsunami and, moreover, it was home to people of three ethnic groups: Tamils, Muslims and Sinhalese.

This study defines social capital conceptually to be 'a resource constituted by trust, reciprocity and networks'.
The study makes a significant distinction between bonding and bridging social capital. Theoretically, bonding social capital refers to the kind of trust, reciprocity and networks that develop within a given social or cultural group founded on one of many possible criteria, such as nationality, ethnicity, caste, religion, age, sex, or any other important grouping variable. Linkages that develop across such groups - that is, relationships that extend beyond the boundary of a group - are described as bridging social capital. Studies in Sri Lanka and elsewhere have shown that, in conflict situations involving different ethnic groups, the role of ethnicity emerges as a prominent fault-line (Colletta \& Cullen, 2000; DeVotta, 2004; Hasbullah, 2000; Korf \& Silva, 2003; Korf, 2004). At a period of heightened ethnic polarisation, this predominant significance of ethnicity for social relationships compelled this study to take ethnicity as the most important grouping variable in the study villages. Thus, intra-ethnic social capital is treated as bonding social capital while inter-ethnic social capital is treated as bridging social capital.

Trust is the cognitive dimension of social capital and it demands both direct and indirect questions to measure it accurately. Indirect questions do not ask whether a person trusts a given person or group, but instead offer concrete situations that involve trust, and record a subject's responses to those situations. While the direct questions openly ask whether respondent has trust in given persons or groups such as people of the next village, the indirect questions, such as the one below, delve into actual social experiences of the respondents.

'Suppose that you fall sick and cannot take care of your children. Can you keep your children with anybody beyond your immediately family members? With how many households can you keep your children?'

The relevance of this question lies in the particular environment in which this study was carried out. It came out in the interviews that in the remote villages there are no daycare centers, and people must rely on other people. The second part of the questions measures the number of households where the respondent can keep his or her children for care and protection. One would not keep children in another's household if there is no trust in that particular family because parents would not risk the safety of their children. Therefore, if a person keeps his or her children in a different household, this is indicative of trust. The significance of using indirect questions is that they have the ability to approximate real-life situations as they unfold in village life.

Networks are the webs of relationships that people have woven throughout their lives, in many different 
life situations and for many different purposes. People represent myriad nodes in this interwoven structure of relationships. These nodes relate to one another in different ways and in different situations, through different mechanisms, and for different requirements. But how much a given node relates to others can vary significantly, on many grounds, and this has implications for that particular node as well as for other nodes. Reciprocity refers to the extent to which people help each other for private or common good. Reciprocity can manifest in different spheres. It could involve a situation in which one individual helps a known individual in the hope that some day the beneficiary will return the favor. At a more benign level, generalised reciprocity symbolises society wherethe individual helps the generalised others in that society, and engages in activities that benefit others in the expectation that everybody else does the same (Putnam, 1995b; Putnam et al., 1993; Uphoff, 2000).

The focus of this study is the village dwellers in six remote war-affected villages. The networks being referred to consist of, for instance, networks with politicians, paddy merchants in the nearby town, government or nongovernment officers, other peasants, and so on. Trust, networks and reciprocity were measured quantitatively using a Likert-like scale, with categories from one to five. The study has utilised both direct and indirect questions to measure networks and reciprocity. The following is an example of a direct question measuring the networks:

'Do you have friends or relatives of the same ethnicity as you who can help you get some work done at a DS office easily? How many do you have?'

The relevance of the above question lies in the fact that there are many things that the DS office can do regarding the life of a villager. If people have some connections, their chances of having their needs met by these offices increases. The above question measures the number of same-ethnicity persons who can offer help but the survey instrument also poses a similar question that measures the number of persons from other ethnic groups. Thus, networks are measured along bonding and bridging lines.

Reciprocity is also measured in both bonding and bridging forms. The following is a typical question measuring bonding reciprocity:

'Are there friends and relatives of the same ethnicity as you who could give you a loan? How many are there?'

In this study the author has attempted to develop culture and context sensitive indictors to measure contemporary levels of social capital. These indicators were developed when the interviews were conducted with the same villagers. Interviews were helpful in identifying what sort of social relationships matter for this society and the kinds of reciprocal relations they have. The indicators capture respondents' friends, relatives, acquaintances, ways of helping each other, and sources of help in case of trouble. Using the survey data, additive indexes were developed to measure current bonding and bridging social capital levels. These indicators are quantified using a Likert scale having levels from one to five ${ }^{4}$. The minimum score a respondent can get in this index is 8; scoring at the lowest level of one for each of the eight indicators. The maximum score is 40; scoring the highest level of five for each of the eight indicators.

\section{Empirical insights}

Table 1 displays the mean bonding social capital score for each village out of a maximum of $40^{5}$. If a household has high levels of trust, networks and reciprocity, then, that household receives a high social capital score. Household scores are aggregated to obtain social capital scores for each village and to compare the social capital levels across the six villages.

Table 1: Mean bonding social capital scores for the six villages

\begin{tabular}{lrrr}
\hline & Tamil & Muslim & Sinhalese \\
\hline Non-poor & 21 & 19 & 30 \\
Poor & 19 & 14 & 19 \\
\hline
\end{tabular}

As Table 1 shows, it is striking to find that bonding social capital is higher among the non-poor villages than among the poor villages within the same ethnicity. This finding questions those studies, which argue that only bridging social capital is relevant for development and that that bonding social capital is a barrier against development.

Table 2: Mean bridging social capital for the six villages

\begin{tabular}{lrrr}
\hline & Tamil & Muslim & Sinhalese \\
\hline Non-poor & 10 & 11 & 17 \\
Poor & 10 & 9 & 11 \\
\hline
\end{tabular}

Indicators for bridging social capital also were developed through the interviews with key informants, who enlightened the researcher on what sort of inter-ethnic relations are pertinent for the lives of the villagers. The bridging social capital index also consists of 8 indicators, which are measured in Likert scales, having levels from one to five ${ }^{6}$. Here also, the minimum score a respondent receives is 8 and the maximum is 40 . Table 2 summarises the mean bridging social capital scores for the six villages out of a maximum of 40 . As 
evidenced in the table above, the study finds that bridging social capital is weak relative to bonding social capital in all the six villages.

The study finds that if a village is high in one dimension of social capital, it is always high in other dimensions as well. The more trusting the individuals are, the more extensive are their networks and reciprocity, and the reverse is also true. This shows the internal consistency among the different dimensions that constitute social capital. But why do different dimensions exhibit internal consistency? It was found that trust, networks and reciprocity have a mutually reinforcing effect on each other at the village level. When people have solid networks, they have more interactions. More interactions generate greater trust. When there is trust, people tend to associate and reciprocate more. Thus, a mutually reinforcing and constructive system is created.

"We cannot deal with people for nothing. If I help somebody and if somebody helps me, we will associate" (Interview 11).

"When I travel from Vavuniya to Batticoloa to Jaffna, I meet Sinhalese and Muslim people.

Even if we don't know their language so well, we somehow relate to them. We are able to understand their attitudes. They like to live in peace with us, I believe" (Interview 14).

The first informant says that interactions result if there is a chance for reciprocity. Not all interactions in fact become reciprocal relations, but the possibility for reciprocity appears to act as an incentive for interactions to take place and for greater trust to develop. As the second informant remarks, greater exposure to people of different ethnicity reduces prejudice against them. Usually, people with less geographic mobility tend to have more negative attitudes of the ethnic other, since they have fewer opportunities of exposure. People who had not had the chance to travel outside of the boundaries of their villages expressed more fear and prejudice about the ethnic other. In some cases, before the ceasefire agreement between the GoSL and the LTTE in 2002, some young Tamils had not seen Sinhalese other than the soldiers. Hence, whatever the qualities that soldiers had shown, were thought to be the qualities of Sinhalese; if they feared the army, they feared the Sinhalese; if they disliked the army, they disliked the Sinhalese. But those such as the second informant (a teacher), who had had more opportunities to associate with the ethnic other, understood Sinhalese as ordinary people and were able to develop a greater level of trust in them than those who had fewer opportunities for interaction.

\section{The impact of violence on social capital}

This study is the first of its kind for this society and hence peoples' memories of past society is the only source on past levels of social capital. Many previous studies have demonstrated that during ethnic conflict situations social capital levels between ethnic groups decrease, while the social capital levels within the groups increase (Colletta \& Cullen, 2000; Colletta et al., 2001; Goodhand et al., 2000, Knack \& Keefer, 1997; Korf \& Silva, 2003). This study has to depend on villagers' memories of the history of the village in order to speak about social capital prior to this study as there is no diachronic data from longitudinal studies.

The most common conflict-related experiences in the study villages are the death of family members, injury to oneself and/or family members, displacement, partial or full destruction of property and inability to access property for some period of time. In total, 92 per cent of the respondents reported experiencing multiple displacements due to conflict. Violence perpetrated by the ethnic other caused people to lose inter-ethnic trust, cease inter-ethnic connections and reciprocity, and to develop these aspects more strongly within the ethnic groups. This could be understood as an increase of bonding social capital and a corresponding decrease of bridging social capital due to conflict-related violence. The study asked the respondents to rate past and present levels of trust within and outside of ethnic group. Table 3 summarises the responses to the two questions about changes in levels of trust, illuminating what people think has happened to bonding and bridging trust in the six villages due to the conflict.

Table 3: The change in bonding and bridging trust within the last five years

\begin{tabular}{lrr}
\hline & $\begin{array}{r}\text { Bonding } \\
\text { Trust }\end{array}$ & $\begin{array}{r}\text { Bridging } \\
\%\end{array}$ \\
\hline Decreased a lot & 0.2 & $\%$ \\
Decreased a bit & 1 & 22 \\
No change & 8 & 30 \\
Increased a bit & 30 & 20 \\
Increased a lot & 61 & 25 \\
\hline
\end{tabular}

Table 3 illustrates that, of the respondents in the six villages, 91 per cent say that bonding trust has increased within the last five years, and 61 per cent say that it has increased a lot. Meanwhile, 52 per cent of respondents reported that bridging trust has decreased, and 22 per cent say that bridging trust has decreased a lot. It becomes apparent that the conflict has contributed 
to a strengthening of bonding trust and a corresponding deterioration in bridging trust.

The following quotes come from interviews with a young Tamil woman aged 30, and a Sinhalese man, aged approximately 40 . They speak of how violence has generated mistrust in the ethnic other.

"Tamils will not trust the Sinhalese people so much. Twice or thrice they have hurt us. Some people burnt our houses. In 1983 our house was burnt. We ran away to the jungle. They followed us to the jungle. I was afraid. So, we are afraid of Sinhalese people. They attacked our people. But now things have changed. So, I am not that afraid now. They pass through our village. When we go to town through their village also, we feel less afraid now" (Interview 17).

"To trust Tamils ... I don't distrust them but from war ... since both sides were hit ... in different occasions I have doubts about them ... no no, I don't distrust but there is a doubt in one corner of everybody's mind. It never disappeared" (Interview 29).

As the first female informant above (who was from the non-poor Tamil village) said, mobs from a distant Sinhalese village burnt and destroyed some of their houses. People from the nearest Sinhalese village did not commit violence against the Tamils here; the two groups are known to each other. Indeed, some Sinhalese from the nearest village received the news about an impending assault early and managed to pass it to their Tamil neighbours. As the Sinhalese informant below illustrates conflict-related violence has diminished inter-ethnic relations, which were found in the past.

"Before the troubles (war) we had good relationships with [Tamils]. We visit them in their homes and they visit ours. We go to them in New Year. Some of our children studied in Jaffna (Tamil) schools. We went to see Tamil films in Vavuniya without telling parents. We had love affairs with Tamil girls and them with our girls" (Interview 29).

Hence, the 'ethnic other' is either directly or indirectly, through the proxy of an armed actor, perceived to be responsible for sufferings of war. Hence, deep mistrust towards the ethnic other was a living reality. The decay of inter-ethnic relations is evidenced by the decreasing number of people capable of speaking the language of the 'ethnic other'. The younger generations now barely speak the language of the other, and rarely associate with the ethnic other.

\section{Does history matter for bonding social capital?}

Some scholars are of the view that social capital is inherited from generation to generation, and that the stock of social capital is cultural heritage: certain types of political institutions, religious teachings, or norms and values which may differ from place to place give rise to social capital and then it is transmitted from one generation to the other (Putnam et al., 1993; Gidwani, 2000; Uphoff \& Wijayaratna, 2000). Of the six villages, the non-poor Sinhalese and Tamil villages have a long history, back to the British colonial era and further. Therefore, these two villages can be considered as 'long-established'. Of the remaining four villages, the poor Sinhalese village is relatively old, but not as long-established as the former two, and the remaining three villages are relatively new settlements. Even within a 'long-established' village, some respondents are older settlers in the sense that their ancestors were born there, while others are migrants who came to the 'long-established' village through marriage or other ways. Yet, at the level of households, there appears to be no correlation between the level of bonding social capital and the length of residency in the village. However, at the village level, the two villages with the longest histories have more bonding social capital.

How can this relationship be explained? Does a history of relationships help the development of a cohesive culture? In the non-poor Sinhalese and Tamil villages people have lived over for at least four generations. Hence, most villagers have interacted with others from childhood and have been socialising together. Their parents were all peasants and thus there was homogeneity in employment. They were bound by kinship and caste. Within the villages, villagers have been followers of the same religion; Buddhism and Hinduism, respectively. Thus, it could be assumed that people shared similar norms, values, aspirations, practices, and so on. Therefore, they possessed the conditions necessary to develop a Durkheimian (1964) 'mechanical solidarity' within the village and developed strong bonds within the boundaries of the village. This led to the development of a subculture with stronger bonding social capital; more trust, greater connectivity and more intense reciprocity among themselves. The non-poor Sinhalese and Tamil villages always had a more cohesive 'we' feeling than the others. They always felt a sense of belonging and a need for collective action in many spheres of life.

Historically, the non-poor villages had significant reciprocal action in relation to agriculture, especially paddy and vegetable farming. The two most important ingredients for paddy and vegetable cultivation are arable lands and irrigation water. In the non-poor villages, historically people were able to convert natural resources into natural assets in order to make productive 
use of them; forest lands were made into arable lands and irrigation channels were built to channel water for cultivation. Collective actions helped the villagers repair and maintain the reservoirs and irrigation channels. Conversion of resources into assets and their maintenance required people to collaborate and hence labor donation (shramadana) became a form of collective action in the field of agriculture. On the contrary, the current people of the 'poor' villages had less social capital to utilise their resources and consequently failed to make productive use of their resources.

Therefore, it is possible that in the non-poor Sinhalese and Tamil villages, bonding social capital had been very strong even in the pre-conflict period, because the villagers had the social, economic, cultural and political conditions conducive to the development of trust, networks and reciprocity. When violence erupted, they already had a sizable stock of social capital built around them, and it is possible that strong bonds became stronger as they faced violence from the 'ethnic other'. Conditions of violence made it necessary for them to cooperate and find refuge from within.

\section{Development}

This study aims to examine the causal relationship between social capital and development in micro settings, in this case, the conflict-affected villages in Vavuniya and secondly to show that social capital can be measured contextually using both qualitative and quantitative methods. The development literature provides many rich approaches to understand what development means and some of the widely known theories may include basic needs approach (Streeten \& Burki, 1978), 'sustainable development' approach, the capability approach (Sen, 1983; 1999), the responsible wellbeing approach (Chambers, 1983; 1997) and the Human Development approaches (UNDP, 1997). What would development mean in the context of a village affected by conflict, where livelihoods have been threatened and shattered by the dynamics of war? This study gives priority to people's economic and material needs, such as food, water, shelter and sanitation, income, education, and so on, although it is recognised that non-material wellbeing is also highly significant and should be included in future studies. This study constructs an index of development, which is sensitive to capture the local material conditions. The informants in the qualitative interviews suggested the indicators to measure their levels of development. The index includes the following items.

Components of development index in this study ${ }^{7}$ :

1. Household income

2. Educational attainment

3. Quality of housing

4. Quality of latrines

5. Perceived quality of drinking water

6. Availability of drinking water

This study constructs a development index with the above indicators to measure material and economic aspects of development at the micro setting of a village. Non-material aspects of development such as security, freedom of movement and freedom to vote are also taken into account within the qualitative data but are not included in the development index, as mixing material and economic aspects with non-material aspects in one aggregate index is too complex for a study of this scale. Above indicators constitute an additive index, which gives an average development score for each respondent. The index is used to compare the level of development across the six villages (Table 4). The six indicators have been measured with a five-point Likert scale, where the maximum score attainable for a household is 30 and the minimum is 6 .

Each household in each village is attributed a development score, and these scores are aggregated to obtain villages means.

\section{Social capital and development: are there causal link- ages?}

The mean social capital scores and the mean development scores presented in Tables 1 and 4 shows the relationship between social capital and development. The non-

Table 4: Development Index (DI)

\begin{tabular}{lr}
\hline Type of village & Mean RDI score \\
\hline Poor Tamil & 18 \\
Poor Muslim & 18 \\
Poor Sinhalese & 17 \\
Non-poor Tamil & 22 \\
Non-poor Muslim & 22 \\
Non-poor Sinhalese & 24 \\
\hline Mean for all villages & 20 \\
\hline
\end{tabular}


poor village records higher levels of bonding social capital in relation to its poorer counterpart of the same ethnicity. With the exception of the non-poor Tamil village, Sinhalese and Muslim non-poor villages have higher bridging social capital compared to their poorer counterparts. Therefore, social capital and development in these micro settings show positive correlation. This can be further tested through a correlation analysis. Table 5 shows the correlation coefficients between bonding and bridging social capital and three aspects of development. Here, development has been broken down to three elements with the assistance of a factor analysis. Thus, DEV1 incorporates income and education, DEV2 incorporates the quality of house and latrine, DEV3 incorporates water quality and availability. NA represents 'natural assets', incorporating the availability of irrigation water and number of acres of lands in possession $^{8}$. The analysis is at the level of households the correlation coefficients have been constructed from the entire sample of 416 households in the six villages.

The data shows that bonding social capital has a strong correlation with income and education (DEV1) and a statistically significant correlation with DEV 2 but the relationship with the quality of water and its availability is weak and statistically insignificant. Bridging social capital has a statistically significant correlation with income and education but is weakly related to DEV 2 and DEV 3. Basically, this means intra-ethnic relationships are highly important for income and education as well as the quality of the house and latrines. However, social capital does not influence the quality of the water or its availability.

People in the non-poor villages have higher bonding social capital, which they leverage to support the education of their children. For example, networks within the same ethnicity have helped them to get access to better schools and secure better jobs. Access to white color and lucrative technical jobs through education as well as through networks is a source of upward mobility in these villages.
At present, bridging social capital does not exert a strong influence on development as bonding social capital. However, it came up in the interviews that connections across ethnicity have contributed to economic prosperity in the past, especially, in relation to agricultural pursuits. For instance, Sinhalese paddy farmers benefited from contacts with Tamil paddy merchants (buyers) and Tamil labourers found employment among Sinhala farmers. Similarly, Tamil vegetable farmers benefited from their contacts with Sinhalese merchants (buyers) and Sinhalese labourers from nearby villages. This economic relationship was, in fact, mutually beneficial because farmers and traders found markets and goods, respectively and job seekers (labourers) found employment. Further, Sinhalese farmers benefited from contacts with Tamil and Muslim agrochemical vendors, who provided chemicals on supposedly interest-free credit. Therefore, people's recollections indicate that bridging social capital has been instrumental for development in the past, though, as a consequence of the conflict, bridging connections are weak at present.

These insights generate a picture of the causal relationships between social capital and development. Although past relationships cannot be tested, this study uses current data to test this relationship through an array of techniques: first, as above, it has undertaken a simple analysis of correlations and then moves to conduct more advanced statistical analyses such a multiple regression analysis and a structural equation modelling $\left(\mathrm{SEM}^{9}\right)$. Figure 1 represents the SEM model that this study tests. This model is constructed based on the qualitative data collected in the study. The qualitative evidence lead the study to hypothesise that social capital is a causal factor of development. However, the study also includes a further set of relevant variables - natural assets - in order to reflect the reality of experience in the war-affected study villages. This study understands two forms of social capital; bonding social capital and bridging social capital, and development is the dependent variable, which is what the study attempts to account for.

Table 5: Correlations between bonding and bridging social capital, and aspects of development

\begin{tabular}{|c|c|c|c|c|c|c|}
\hline & $\begin{array}{r}\text { Bonding } \\
\text { Social Capital }\end{array}$ & $\begin{array}{r}\text { Bridging } \\
\text { Social Capital }\end{array}$ & DEV1 & DEV2 & DEV3 & NA \\
\hline Bonding Social Capital & 1 & $0.501\left(^{* *}\right)$ & $0.501\left(^{* *}\right)$ & $0.329\left(^{* *}\right)$ & $0.255\left(^{* *}\right)$ & $0.502(* *)$ \\
\hline Bridging Social Capital & $0.501\left(^{* *}\right)$ & 1 & $0.393\left({ }^{* *}\right)$ & $0.190\left(^{* *}\right)$ & $0.146\left(^{* *}\right)$ & $0.367\left(^{* * *}\right)$ \\
\hline DEV1 & $0.501\left(^{* *}\right)$ & $0.393(* *)$ & 1 & $0.356\left(^{* *}\right)$ & $0.300\left(^{* *}\right)$ & $0.480(* *)$ \\
\hline DEV2 & $0.329\left({ }^{* *}\right)$ & $0.190\left({ }^{* *}\right)$ & $0.356\left({ }^{* *}\right)$ & 1 & $0.208\left({ }^{* *}\right)$ & $0.504\left({ }^{* *}\right)$ \\
\hline DEV3 & $0.255\left({ }^{* *}\right)$ & $0.146\left({ }^{* *}\right)$ & $0.300\left({ }^{* *}\right)$ & $0.208\left({ }^{* *}\right)$ & 1 & $0.300(* *)$ \\
\hline NA & $0.502\left(^{* *}\right)$ & $0.367\left(^{* *}\right)$ & $0.480\left({ }^{* *}\right)$ & $0.504\left(^{* *}\right)$ & $0.300\left(^{* *}\right)$ & 1 \\
\hline
\end{tabular}

** Correlation is significant at the 0.01 level (2-tailed). 


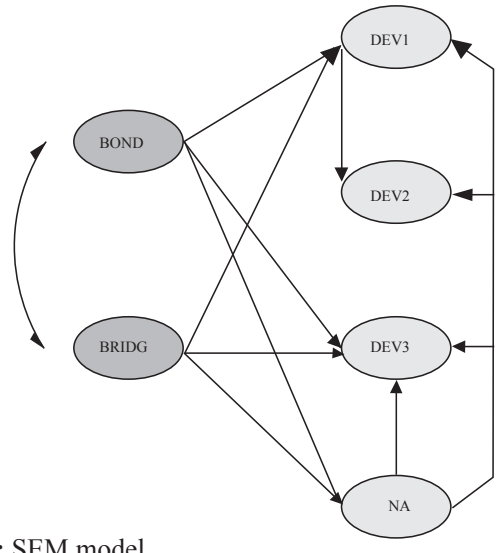

Figure 1: SEM model

In this SEM model, in line with existing theory, BOND and BRIDGE have been drawn as explanatory variables, each of which has three arrows in outwards direction. This means that bonding and bridging social capital are hypothesised to influence the four dependent variables: DEV1, DEV2, DEV3 and NA. Since SEM analysis enables the study to dissect a theoretical construct into its constitutive dimensions, this study divides development into three interrelated aspects for analysis of its constituent parts. NA is also hypothesised to influence DEV1 and DEV3, while DEV1 is hypothesised to influence DEV2. Thus, NA and DEV1 are dependent variables in relation to BOND and BRIDGE, but are explanatory variables in relation to DEV 2 and DEV 3. The double-headed arrow between BOND and BRIDGE implies that there is factor correlation between bonding and bridging social capital.
Many social capital studies have concluded that bridging social capital is more important than bonding social capital for development related outcomes (Eklinder-Frick et al., 2012; Narayan, 1999; Paxton, 2002; Putnam, 1995b). However, the qualitative information presented earlier and results observed in Table 4 have contradicted this view. Bridging social capital has a statistically significant correlation to income and education, but its correlation with other variables is weak. Therefore, bonding social capital comes out as more relevant to the dimensions of development in the selected micro settings. Although correlations do not prove the existence of causal relationships, they can provide indications of potential causal relationships. The study must determine which of the explanatory variables most strongly explains the variation in the dependent variable, development. For this purpose, the study conducts a multiple regression analysis for the four variables in the model. Although development is divided into three dimensions in the SEM analysis, it is kept undivided in the regression analysis, as at this stage the study is interested in determining the relative significance of the explanatory variables in relation to the dependent variable. Table 6 and 7 summarise the results from the analysis ${ }^{10}$.

As Table 6 illustrates, the three explanatory variables in the model account for 42 per cent of the variance in rural development. The individual contribution of each explanatory variable can be understood by looking at the Beta values ${ }^{11}$ in Table 7 (standardised coefficients), where

Table 6: Model summary *

\begin{tabular}{lrrrrr}
\hline Model & R & R Square & $\begin{array}{r}\text { Adjusted R } \\
\text { Square }\end{array}$ & $\begin{array}{r}\text { Std. Error of } \\
\text { the Estimate }\end{array}$ & $\begin{array}{r}\text { Durbin- } \\
\text { Watson }\end{array}$ \\
\hline 1 & $0.652{\left({ }^{* *}\right)}^{*}$ & 0.426 & 0.421 & 2.882 & 1.414 \\
\hline
\end{tabular}

* Dependent Variable: DEVELOPMENT

** Predictors: (Constant), NA (natural assets), Bridging Social Capital, Bonding Social Capital

Table 7: Coefficients *

\begin{tabular}{|c|c|c|c|c|c|c|c|}
\hline \multirow[t]{2}{*}{ Model } & \multicolumn{2}{|c|}{ Unstandardised Coefficients } & \multirow{2}{*}{$\begin{array}{r}\text { Standardised } \\
\text { Coefficients } \\
\text { Beta }\end{array}$} & \multirow[t]{2}{*}{$\mathrm{t}$} & \multirow[t]{2}{*}{ Sig. } & \multicolumn{2}{|c|}{$\begin{array}{r}\text { Collinearity } \\
\text { Statistics }\end{array}$} \\
\hline & $\mathrm{B}$ & Std. Error & & & & Tolerance & VIF \\
\hline (Constant) & 13.100 & 0.477 & & 27.437 & 0.000 & & \\
\hline NA & 0.768 & 0.072 & 0.46 & 10.634 & 0.000 & 0.730 & 1.370 \\
\hline $\begin{array}{l}\text { Bonding Social } \\
\text { Capital }\end{array}$ & 0.138 & 0.026 & 0.25 & 5.310 & 0.000 & 0.632 & 1.582 \\
\hline $\begin{array}{l}\text { Bridging Social } \\
\text { Capital }\end{array}$ & 0.035 & 0.032 & 0.05 & 1.117 & 0.265 & 0.732 & 1.367 \\
\hline
\end{tabular}

" Dependent Variable: DEVELOPMENT 
the information is given in standard deviation units. Accordingly, natural assets and bonding social capital emerge as the most influential of the three explanatory variables in the model. These two variables - natural assets and bonding social capital - have significant effects on development, whereas the effect of bridging social capital is not significant. This regression analysis further confirms the preliminary results obtained through the correlation analysis.

According to Figure 1, both forms of social capital are hypothesised to have a causal influence on the three dimensions of development, DEV1, DEV2, DEV3, and also on natural assets (NA), which again influences some dimensions of development. The model essentially means that when people have bonding and bridging social capital, it promotes certain dimensions of development, either directly or indirectly. Water and land are natural resources and that social capital cannot influence their existence. However, observations in the study villages revealed that to convert resources into productive assets, lands must be converted to arable lands and water must be stored and channelled to the fields. Evidence that emerged in the interviews showed that in the study villages people have turned natural resources into natural assets through collective actions. In a SEM analysis it is necessary to distinguish between direct and indirect causal effects. For example, in Figure 1, the two forms of social capital have arrows going out from them and reaching two dimensions of development. These arrows represent direct causal effects. An explanatory variable can simultaneously have both direct and indirect effects on a given dependent variable. For example, bonding social capital directly influences DEV1 and NA, and NA in turn influences DEV1. The influence that bonding exerts on DEV1 through NA is an indirect effect. No arrow reaches DEV2 from any form of social capital, however this does not mean that social capital has no influence on DEV2. Both forms of social capital are hypothesised to causally influence this dimension indirectly: social capital causally influences DEV1, which in turn influences DEV2. Further, social capital influences NA, which influences DEV1, which again influences DEV2. Thus, although there is no arrow extending from NA to DEV2, it also has an indirect effect on DEV2.

As mentioned above, since this model involves several key assumptions and a set of hypotheses, the SEM exercise is confirmatory rather than exploratory. The set of hypotheses were generated by the qualitative information and serves as a guiding light to linking the variables. A SEM exercise tests how consistent a model is with the empirical data. To check this consistency, a LISREL model generates various 'fit indexes', which indicates how 'good' or 'bad' the model is. Figure 2 represents the full model which displays all of the related variables $^{12}$.

In the LISREL model (Figure 2), the rectangle-shaped boxes on the left side represent indicators of bonding and bridging social capital ${ }^{13}$, while the rectangle-shaped boxes on the right side represent indicators for the three

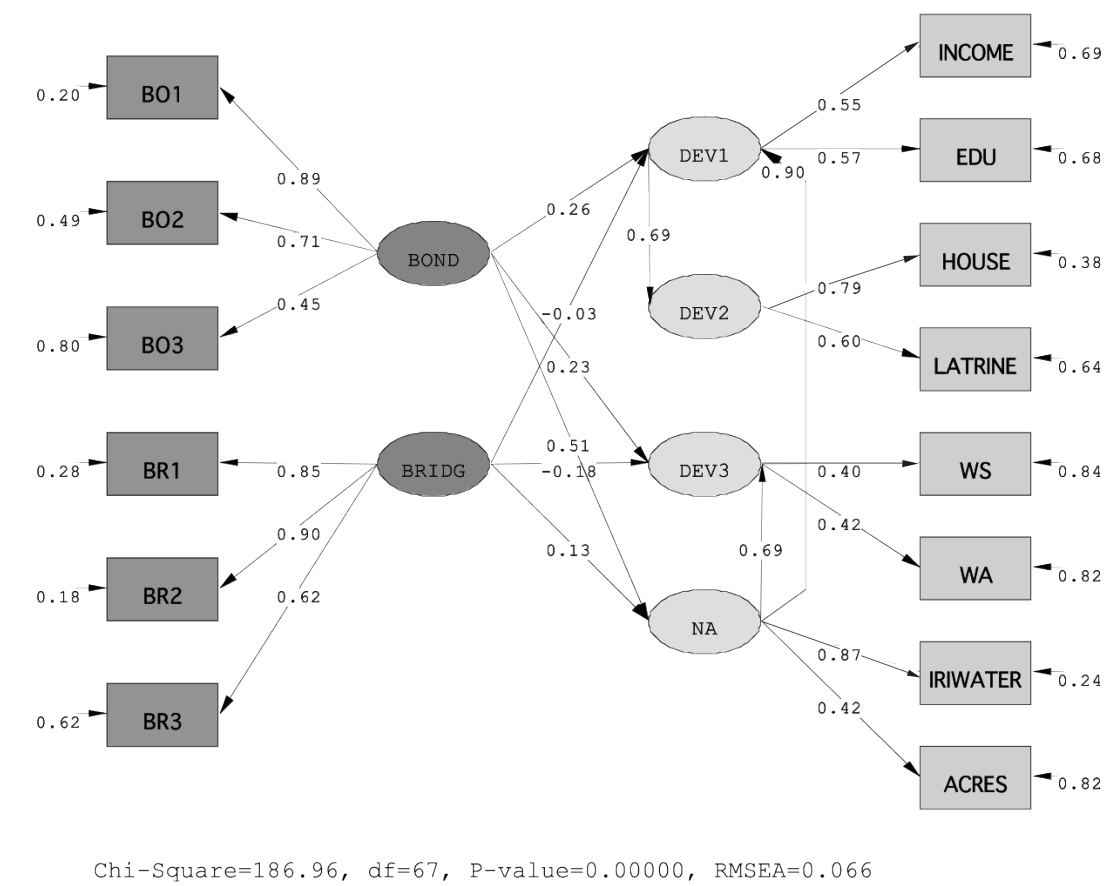

Figure 2: The LISREL model 
dimensions of development and natural assets. The arrows, which reach the indicator variables (rectangles), are helpful in understanding the utility of the indicators. (The figures appearing in the middle of those arrows signify the factor loadings, which are standardised measures ranging from 0 to plus or minus 1 . The closer the loading is to 1 , the better the indicator is in measuring what they purport to measure ${ }^{14}$ (Diamatopoulos \& Siguaw, 2000). However, what is most significant are the parameter estimates among the factors. These can be observed in the middle of the arrows connecting various factors (oval-shaped circles). All figures are standardised estimates, and represent the causal influences according to the hypotheses.

The path diagram in Figure 2 exhibits all of the direct effects that explanatory variables exert on the dependent variables. At the level of households in the six villages, the direct effect of bonding social capital on income and education (DEV1) is 0.26 . If one goes for a strictly technical interpretation, this can be read as follows; for every unit increase in bonding social capital, there is a 0.26 increase in income and education. The direct effect of bridging social capital on income and education is -0.03 , which is not significant. Given that this effect is extremely small, the fact that it is a negative effect should not generate any contradiction. The relative direct effect of the two forms of social capital on other dimensions of development and natural assets, and the direct effect of natural assets on dimensions of development are explicit in the diagram. Nevertheless, the path diagram shows only the direct effects, but it is also necessary to take account of the indirect effects in order to appreciate the total effects. As Table 8 shows, the total effects are much higher than the direct effects seen in the path diagram, as the indirect effects have been added in the table.

Table 8: Standardised total and indirect effects

\begin{tabular}{lcr}
\hline & BOND & BRIDG \\
\hline Standardised Total Effects of KSI on ETA ${ }^{15}$ & & \\
DEV1 & 0.72 & 0.09 \\
DEV2 & 0.50 & 0.06 \\
DEV3 & 0.59 & -0.09 \\
NA & 0.51 & 0.13 \\
Standardised Indirect Effects of KSI on ETA & & \\
DEV1 & 0.46 & 0.12 \\
DEV2 & 0.50 & 0.06 \\
DEV3 & 0.36 & 0.09 \\
NA & -- & - \\
\hline
\end{tabular}

As Table 8 illustrates, bonding social capital has different total effects on the three dimensions of development, and also on natural assets. Bonding has its strongest influence on DEV1 (effect of 0.72), which represents income and education. Further, bonding has a significant influence on DEV2 (housing and latrines) and DEV3 (water and its availability). A large part of the total influence of bonding comes through indirect influence, that is, by influencing other variables, which in turn influence dimensions of development. Bonding also strongly influences natural assets. Bridging social capital has no noteworthy effect on any dimension of development or natural assets. Table 9, below, demonstrates that natural assets strongly influence all dimensions of development.

Table 9: Standardised total effects of ETA on ETA ${ }^{16}$

\begin{tabular}{lcccc}
\hline & DEV1 & DEV2 & DEV3 & NA \\
\hline DEV1 & -- & -- & - & 0.90 \\
DEV2 & 0.69 & -- & - & 0.62 \\
DEV3 & -- & -- & -- & 0.69 \\
NA & -- & -- & -- & - \\
\hline
\end{tabular}

The effect of natural assets on the three dimensions of development is very strong. Natural assets have an almost one to one relationship with income and education (effect of 0.90 ). In terms of total effects, natural assets strongly influence the other two dimensions of development, DEV2 (housing and latrines) and DEV3 (water and its availability). Therefore, estimates from the LISREL model show that, as a causal factor, natural assets are important for all dimensions of development.

The SEM analysis confirms the patterns of results obtained from the correlation analysis and the regression analysis although some difference can be observed owing to the fact that SEM analysis also takes indirect effects into account. However, a note of caution is required here. As mentioned earlier in this paper, the sole purpose of these complex quantitative analyses is to test hypotheses generated by qualitative data. Thus, parameter estimates (direct and indirect effects) are used only for illustrative and confirmatory purpose. It is extremely difficult to speak about social phenomena in 'numbers'. Thus, to say that one unit increase of $\mathrm{X}$ lead to 0.5 increase in $\mathrm{Y}$ without guidance from qualitative information would actually not make much sense. In the real and complex world of human life, social relationships would not operate in such simple fashion. Further, the use of Likert scale and composite indexes may not permit the study to make solid claims on the exact extent of causality. Yet, importantly, that fact that statistical results confirm the directions and nature of causality found by qualitative ethnographic information, give credence to the employment of 'numbers' to understand complex social phenomena. 


\section{CONCLUSIONS; EXPLAINING DEVELOPMENT}

The significance of this study lies in its findings as well as the methodology used to generate these findings. The study uses a mixed method model of qualitative and quantitative data collection techniques and analysis. Further, this study makes a rigorous effort to measure social capital using indicators developed in the field through the qualitative interviews. The study illustrates how a mixed model of interviews and a survey can complement each other and generate much richer data than otherwise would have been the case. As mentioned earlier, a major research gap in social capital literature is the inconsistent views about the utility of bonding social capital as regards to development in micro settings, especially under conditions of violent conflict. This study fills a research gap by demonstrating how bonding social capital actually works to support development at micro settings at a time of conflict. Therefore, this challenges the commonly held view that bonding social capital is a regressive factor, which curtails development. The study does not, however, reject the importance of bridging social capital, although its effect on development at present time is weak; it has had historical significance for development, although conflict and violence between ethnic groups have had a debilitating influence on crossethnic ties. The study challenges the prevailing 'either bonding or bridging' dichotomy, which suggests that only one type of social capital relates to development. This study notes that in the particular context and culture, bonding and bridging social capital are not dialectically opposed, and are not inversely related; rather, they are mutually reinforcing.

Nonetheless, neither forms of social capital can exhaustively explain development, as the study finds that natural assets have significant power as causal factors of development. Thus, this study concludes that, as far as the study villages are concerned, bonding social capital and natural assets are significant causal factors in development.

This study argues that the causal factors of development function in combination, rather than in isolation. Development requires a positive interplay between these factors. One of the strongest criticisms against social capital studies is that their reasoning suffers from 'circularity' (Harris \& De Renzio, 1997; Portes, 1998; 2000; Sobel, 2002). This study finds that causal factors of development interact to create mutually reinforcing virtuous systems. It shows that bonding social capital, along with other factors, leads to development, which in turn helps people build more and new types of social capital, including bridging social capital. Once people have achieved a certain level of development, it stimulates people to cultivate new and more broad-based social capital at both the individual and village level. Also, education offers people the opportunities to be employed in state and non-state work places, away from village, and this helps them to build more social capital. A similar reciprocal relationship exists between natural assets and development. Natural assets are causative of development in its early stages. However, at later stages, income and education can also help people improve their natural assets. People in non-poor villages are in a better position to obtain the services of state and nonstate institutions to repair reservoirs and canals, due to their higher incomes and educational levels. In this way, there emerges a mutually reinforcing system. However, where the conditions are unfavourable (that is, lower social capital and low natural assets), development is not stimulated. In order to change the conditions of places such as the poor villages under this study, the poverty circle needs to be broken with some social mobilisation, which may include external assistance.

\section{END NOTES}

1. The study was carried out in the year 2005 for the Doctoral Thesis on Rural development through social capital? An inquest on the linkages between social capital and rural development in war-torn villages in Sri Lanka, published by the University of Gotheburg. The actual village names are not disclosed with a view to protect anonymity.

2 . This study uses the term 'non-state' institutions to refer to non-governmental organisations.

3. It is somewhat problematic to identify an appropriate terminology to reflect a situation that is contextually the 'opposite' of 'poor'. In the study villages, certain people enjoy 'higher' living standards than poor people in the same village. Thus, this study uses the term 'non-poor' to refer to households with relatively higher living standards. In some villages, most households are relatively homogenously either poor or non-poor. Accordingly, those villages are referred to as 'poor' or 'non-poor', to reflect the relative living conditions of the majority in the villages. The initial categorisation of villages into poor and non-poor was performed based on the district poverty profile (an official document) and initial observations of the physical conditions in the villages such as the conditions of housing, infrastructure and people's occupations. This was necessarily a subjective categorisation, performed for the purpose of selecting an appropriate sample of subject villages for the study. 
4. The survey instruments posed about 20 questions to measure bonding and bridging social capital. A factor analysis and item analysis helped in reducing the number of indicators and to select most significant indicators.

5. Scores have been rounded up to the nearest integer.

6. The indicators are not displayed due to word limitations but interested reader can request detailed information from the author.

7. Actual household income and the actual years of education was collected. Other items were measured in a Likert scale. All items are given equal weight in accordance with respondents perceptions towards these items. Giving equal weight also reduces potential bias, which might arise due to unknown inaccuracies such as underestimation of incomes by respondents.

8. The study could not consider other kinds of natural resources such as livestock as previous displacements had obliterated most of livestock. The study considers land possession but not operated land holding as tenant farming was less common in the study villages.

9. A data processing programme called LISREL is used to perform a SEM analysis.

10. Given that there is no unilateral agreement in social capital literature about the relative significance of the explanatory variables used in the model, it uses the 'forced entry' method to enter the variables into the regression analysis. However, the study also ran regression analyses with other methods and found that the results do not vary significantly.

11. Beta values have been rounded up to the nearest integer.

12. The structural equation model is also referred to as a LISREL model because the LISREL data analysis package has been used for the analysis.

13. Social capital variables have eight indicators each but as this study has used a 'parceling technique' to combine several indicator variables, only six indicators are represented in the diagram above.

14. Figure 2 reveals that the lowest standardised loading in the model is 0.4 , and most loadings are above 0.5 or 0.6 . This means that this measurement model is within the range of reasonableness and acceptability for a social science study. In the study model, the chi-square is significant, and hence if this statistic is trusted, the model cannot be accepted. Yet, the chi-square statistic cannot be used in as a good 'fit index' in the case of this study in which the data are non-normal, skewed and have a high kurtosis. Hence, many social science SEM analyses use RMSEA, which is based on chisquare, but is considered more reliable. In the case of RMSEA, values below 0.05 indicate good fit, between 0.05-0.08 reasonable fit, between 0.08-0.10 mediocre fit, and above 0.10 poor fit (Diamatopoulos \& Siguaw, 2000). The SEM model in this study has a RMSEA of 0.06 , which is generally considered to be acceptable and reasonable in statistical literature, given the type and characteristics of the data. Therefore, from a technical, purely statistical point of view the model this study has constructed and tested is acceptable.

15. KSI means exogenous (explanatory) latent variables; ETA means endogenous explanatory or dependent latent variables.

16. ETA on ETA stands for effects of explanatory endogenous variables on dependent endogenous variables.

\section{REFERENCES}

Amunugama, S. (1964) Rural credit in Ceylon: Some Sociological Observations, The Ceylon Journal of Historical and Social Studies, 7(2), pp: 135-43.

Bourdieu, P. (1986) 'The Forms of Capital', In Richardson, J. G. (ed) Handbook of Theory and Research for the Sociology of Education, New York: Greenwood Press.

Bourdieu, P. (1998) Practical Reason, Oxford: Polity Press.

Bourdieu, P. (1990) The Logic of Practice, Oxford: Polity Press.

Chambers, R. (1983) Rural Development: Putting the Last First, Harlow: Longman.

Chambers, R. (1997) Whose Reality Counts? Putting the First Last, London: Intermediate Technology Publications.

DOI: https://doi.org/10.3362/9781780440453

Coleman, J. (1988) Social Capital in the Creation of Human Capital, American Journal of Sociology, 94 (Supplement), pp: S95-S120.

DOI: https://doi.org/10.1086/228943

Coleman, J. (1993) The Design of Organizations and the Right to Act, Sociological Forum, 8(4), pp: 527-46.

DOI: https://doi.org/10.1007/BF01115210

Colletta, Nat. J. \& Cullen, M. L. (2000) Violent Conflict and the Transformation of Social Capital: Lessons from Cambodia, Rwanda, Guatemala, and Somalia, Washington DC: The World Bank. 
Colletta, Nat J., Lim, T.G. \& Kelles-Viitanen, A. (eds) (2001) Social Cohesion and Conflict Prevention in Asia: Managing Diversity through Development, Washington, D.C, The World Bank.

D' Silva, E. \& Pai, S. (2003) Social Capital and Collective Action: Development Outcomes, Forest Protection and Waste Land Development, Economic and Political Weekly, April, pp: 1404-1415.

DeVotta, N. (2004) Blowback: Linguistic Nationalism, Institutional Decay, and Ethnic Conflict in Sri Lanka, California: Stanford University Press.

Diamantopoulos, A. \& Siguaw, J. A. (2000) Introducing LISREL, London: Thousand Oaks and New Delhi: Sage Publications.

DOI: https://doi.org/10.4135/9781849209359

Durkheim, E. (1964) The Division of Labor in Society (Trans. George Simpson), New York: Free Press.

Eklinder-Frick, J., Eriksson, L. T. \& Hallén, L. (2012) Effects of social capital on processes in a regional strategic network, Industrial Marketing Management, 41(5), pp: 800-806.

DOI: https://doi.org/10.1016/j.indmarman.2012.06.007

Fine, B. \& Green, F. (2000) Economics, Social Capital, and the Colonization of the Social Sciences, In Schuller, T., Stephen, B. \& John, F. (eds) Social Capital: Critical Perspectives, Oxford: Oxford University Press.

Fine, B. (1999) The Development State Is Dead - Long Live Social Capital?, Development and Change, 30, pp: 1-19.

DOI: https://doi.org/10.1111/1467-7660.00105

Fine, B. (2003) Review Essay: Social Capital: The World Bank's Fungible Friend, Journal of Agrarian Change, 3(4) October, pp: 586-603.

DOI: https://doi.org/10.1111/1471-0366.00068

Fox, J. (1997) Policy Arena: The World Bank and Social Capital: Contesting the Concept in Practice, Journal of International Development, 9(7), pp: 963-71.

D O I : h t t p s : / / d o i org/ 10.1002 / ( S I C I ) 1099 1328(199711)9:7<963::AID-JID499>3.0.CO;2-D

Fukuyama, F. (1995) Social Capital and the Global Economy, Foreign Affairs, pp: 89-103.

DOI: https://doi.org/10.2307/20047302

Gidwani, V. (2000) New Theory of New Dogma? 'A Tale of Social Capital and Economic Development from Gujarat, India', Journal of Asian and African Studies, 37(2), pp: 83-112. DOI: https://doi.org/10.1177/002190960203700204

Goodhand, J., Klem, B., Fonseka, D., Keethaponcalan, S. I. \& Sardesai, S. (2005) Aid, Conflict, and Peacebuilding in Sri Lanka, 2000-2005 (Vol. 1), Colombo: Asia Foundation.
Harriss, J. \& De Renzio, P. (1997) Policy Arena: 'Missing link' or analytically missing?: The concept of social capital, In Harriss, J (ed) An introductory bibliographic essay, Journal of international development, 9(7), pp: 919-937.

Harris, J. (2001) Depoliticizing Development: The World Bank and Social Capital, London: Anthem press.

Hasbullah, H. S. (2000) Ethnic Conflict and the Prospects for Rehabilitation and Reconstruction: The Eastern Province, In de Silva, K. M. \& Peiris, G. H. (eds) Pursuit of Peace in Sri Lanka: Past Failures and Future Prospects, pp: 327-44, Kandy: ICES.

Helliwell, J. F. \& Putnam, R. D. (1995) Economic Growth and Social Capital in Italy, Eastern Economic Journal, 21(3), pp: 295-307.

Hulme, D. \& Shepherd, A. (2003) Conceptualizing Chronic Poverty, World Development, 31(3), pp: 403-23.

DOI: https://doi.org/10.1016/S0305-750X(02)00222-X

Husen. N. A., Tim, K. L. \& Khalid, H. A. S. (2017) Social Capital and Agricultural Technology Adoption among Ethiopian Farmers, American Journal of Rural Development, 5(3), pp: 65-72.

Jayamaha, R. (1990) Innovative Approaches to Poverty Alleviation Through Banking and Financial Institutions - A case for Sri Lanka, Staff Studies, 20 (1\&2), pp: 29-39.

Kelley, D. J., Brush, C. G., Greene, P. G. \& Litovsky, Y. (2010) Global entrepreneurship monitor- Women's Report, Babson College and the Global Entrepreneurship Research Association (GERA).

King, P. E. \& Furrow, J. L. (2004) Religion as a Resource for Positive Youth Development: Religion, Social Capital, and Moral Outcomes, Developmental Psychology, 40(5), pp: 703771.

DOI: https://doi.org/10.1037/0012-1649.40.5.703

Knack, S. \& Keefer, P. (1997) Does Social Capital have an Economic Payoff? A Cross-country Investigation, Quarterly Journal of Economics, 112, pp: 1251-1288.

DOI: https://doi.org/10.1162/003355300555475

Knack, S. (2002) Social Capital, Growth and Poverty: A Survey of Cross-country Evidence', In Grootaert, C. \& Van Bastelaer, T. (eds) The Role of Social Capital in Development, Cambridge: Cambridge University Press.

DOI: https://doi.org/10.1017/CBO9780511492600.004

Korf, B. \& Silva, K. T. (2003) Poverty, Ethnicity and Conflict in Sri Lanka, Paper Presented at the Conference 'Staying Poor: Chronic Poverty and Development Policy', $7^{\text {th }}-9^{\text {th }}$ April 2003, UK: University of Manchester (Unpublished).

Korf, B. (2004) War, Livelihoods and Vulnerability in Sri Lanka, Development and Change, 35(2), pp: 275-95.

DOI: https://doi.org/10.1111/j.1467-7660.2004.00352.x 
Lin, N. (1999) Building a Network Theory of Social Capital, Connections, 22(1), pp: 28-51.

Malecki, E. J. (2012) Regional social capital: Why it matters, Regional Studies, 46(8), pp: 1023-1039.

DOI: https://doi.org/10.1080/00343404.2011.607806

McShane, C. J., Turnour, J., Thompson, M., Dale, A., Prideaux, B. \& Atkinson, M. (2016) Connections: the contribution of social capital to regional development, Rural Society, 25(29), pp: 154-169.

DOI: https://doi.org/10.1080/10371656.2016.1194326

Michelini, J. J. (2013) Small farmers and social capital in development projects: Lessons from failures in Argentina's rural periphery, Journal of Rural Studies, 30, pp: 99-109.

DOI: https://doi.org/10.1016/j.jrurstud.2013.01.001

Mozumdar L., Farid, K. S. \& Sarma, P. K. (2017) Relevance of social capital in women's business performance in Bangladesh, Journal of Bangladesh Agricultural University, 15(1), pp: 8794.

DOI: https://doi.org/10.3329/jbau.v15i1.33533

Narayan, D. \& Pritchett, L. (1997) Cents and sociability: household income and social capital in rural Tanzania (Vol. 1796), World Bank Publications.

Narayan, D. \& Pritchett, L. (2000) Social Capital: Evidence and Implications, In Dasguptha, P. (ed) Social Capital: A Multifaceted Perspective, Herndon: The World Bank.

Narayan, D. (1999) Bonds and bridges: Social capital and poverty (Vol. 2167), World Bank Publications.

Nejadi, F., Abbasi, E. \& Choobchian, S. (2017) The Role of Combating Desertification Projects in Promotion of Local People's Social Capital (The Case of Shahdad Carbon Sequestration Project), Journal of Rural Research, 7(4), pp: 604-617.

DOI: https://doi.org/10.21859/jjr-07042

Paxton, P. (1999) Is Social capital declining In United States? A multiple Indicator Assessment, American Journal of Sociology, 105, pp: 88-127.

DOI: https://doi.org/10.1086/210268

Paxton, P. (2002) Social Capital and Democracy: An Interdependent Relationship, American Sociological Review, 67(2), pp: 254-77.

DOI: https://doi.org/10.2307/3088895

Portes, A. \& Sensenbrenner, J. (1993) Embeddedness and Immigration: Notes on the Social Determinants of Economic Action, American Journal of Sociology, 93(6), pp: 1320-50.

DOI: https://doi.org/10.1086/230191
Portes, A. (1998) Social Capital: Its origins and Applications in Modern Sociology, Annual Review of Sociology, 24, pp: 1-24. DOI: https://doi.org/10.1146/annurev.soc.24.1.1

Portes, A. (2000) The Two Meanings of Social Capital, Sociological Forum, 15(1), pp: 1-12.

DOI: https://doi.org/10.1023/A:1007537902813

Putnam, R. D. (1993) The Prosperous Community: Social Capital and Public Life, The American Prospect, 4 (13), pp: $35-42$.

Putnam, R. D. (1995a) Bowling Alone: America's Declining Social Capital, Journal of Democracy, 6 (1), pp: 65-78.

DOI: https://doi.org/10.1353/jod.1995.0002

Putnam, R. D. (1995b) Tuning in, Tuning out: The Strange Disappearance of Social Capital in America, Political Science and Politics, 28(4), pp: 664-83.

DOI: https://doi.org/10.1017/S1049096500058856

Putnam, R. D., Leonardi, R. \& Nanetti, R. (1993) Making Democracy Work: Civil Traditions in Modern Italy, Princeton, New Jersey: Princeton University Press.

Quetulio-Navarra, M., Zetter, R., Niehof, A. \& Zhao, F. (2017) Getting By or Getting Ahead: Resettlement Inputs and Social Capital in Involuntary Resettlement, Journal of Population and Social Studies, 25(2), pp: 99 - 118.

DOI: https://doi.org/10.25133/JPSSv25n2.002

Sen, A. (1983) Development: Which Way Now?, The Economic Journal, 93, pp: 745-62.

DOI: https://doi.org/10.2307/2232744

Sen, A. (1999) Development as Freedom, Oxford: Oxford University Press.

Sobel, J. (2002) Can We Trust Social Capital, Journal of Economic Literature, XL(1), pp: 139-54.

DOI: https://doi.org/10.1257/jel.40.1.139

Streeten, P. \& Burki, S. J. (1978) Basic Needs: Some Issues, World Development, 6(3), pp: 411-21.

DOI: https://doi.org/10.1016/0305-750X(78)90116-X

Taruvinga, B., Ndou, P., Hlerema, I. N., Maraganedzha, T. L., Du Plooy, C. P. \& Venter, S. (2017) Fostering linking social capital for successful agricultural development projects in South Africa, Agrekon, 56(1), pp: 28-39.

DOI: https://doi.org/10.1080/03031853.2017.1283243

UNDP (1997) Human Development Report, New York/ Oxford: Oxford University Press.

Uphoff, N. \& Wijayaratna, C. M. (2000) Demonstrated Benefit from Social Capital: The Productivity of Farmer Organizations 
in Gal Oya, Sri Lanka, World Development, 28(2), pp: 1875-90. DOI: https://doi.org/10.1016/S0305-750X(00)00063-2

Uphoff, N., Esman, M. \& Krishna, A. (1998) Reasons for success. Learning from Instructive Experiences in Rural Development, West Hartford, Conn.: Kumarian Press.

Uphoff, N. (2000) Understanding Social Capital: Learning from the Analysis and Experience of Participation', In Dasguptha, P. \& Serageldin, I. (eds) Social Capital: A Multifaceted Perspective, Herndon: The World Bank.

Uslaner, E. M. \& Conley, R. S. (2003) Civic Engagement and Particularized Trust: The Ties that Bind People to Their Ethnic Communities, American Politics Research, 31(4), pp: 331-60. DOI: https://doi.org/10.1177/1532673X03031004001

Westlund, H. \& Adam, F. (2010) Social capital and economic performance: A meta-analysis of 65 studies, European Planning
Studies, 18(6), pp: 893-919.

DOI: https://doi.org/10.1080/09654311003701431

Widmalm, S. (2005) The Unity of Bonding Social Capital, Journal of Civil Society, 1(1), pp: 75-95.

DOI: https://doi.org/10.1080/17448680500210680

Woolcock, M. (1998) Social Capital and Economic Development: Toward a Theoretical Synthesis and Policy Framework, Theory and Society, 27, pp: 151-208.

DOI: https://doi.org/10.1023/A:1006884930135

Woolcock, M. (2002) Social Capital in Theory and Practice: Where Do we Stand?', In Isham, J., Kelly, T. \& Ramaswamy, S. (eds) Social Capital and Economic Development: Well-being in Developing Countries, Cheltenham/Northampton: Edward Elgar.

DOI: https://doi.org/10.4337/9781781950388.00011 